\title{
Organic matter fractions in soil under coffee with split applications of phosphorus and water regimes
}

\author{
${ }^{1}$ FAV/UnB. Brasília, DF. E-mail: lga.agro@gmail.com \\ ${ }^{2}$ FAV/UnB. Brasília, DF. E-mail: cicerocf@unb.br (Autor correspondente) \\ ${ }^{3}$ IFNMG. Arinos, MG. E-mail: inacioifnmg@hotmail.com \\ ${ }^{4}$ FAV/UnB. Brasília, DF. E-mail: lucrecia@unb.br (Bolsista CNPq) \\ ${ }^{5}$ Embrapa Cerrados, Planaltina, DF. E-mail: omar.rocha@embrapa.br \\ ${ }^{6}$ Embrapa Cerrados, Planaltina, DF. E-mail: antonio.guerra@embrapa.br
}

Larissa G. Araújo ${ }^{1}$, Cícero C. de Figueiredo ${ }^{2}$, Inácio B. Borges ${ }^{3}$, Maria L. G. Ramos ${ }^{4}$, Omar C. Rocha ${ }^{5}$ \& Antonio F. Guerra ${ }^{6}$

\section{Key words:}

labile carbon

phosphate fertilizer

humic substances

\begin{abstract}
A B S T R A C T
Phosphorus fertilization and irrigation management are essential practices to increase coffee yields, though information is scarce about the effect of these practices on organic matter fractions of soils of the 'Cerrado' (savanna-like vegetation). The purpose of this study was to evaluate organic matter fractions of a clayey Oxisol under coffee with split applications of phosphorus $(\mathrm{P})$ and water regimes. The experimental design was a randomized block with $3 \times 2$ factorial arrangement with three split applications of $\mathrm{P}\left(\mathrm{P} 1: 300 \mathrm{~kg} \mathrm{ha}^{-1} \mathrm{P}_{2} \mathrm{O}_{5}\right.$ applied annually of which $2 / 3$ applied in September and 1/3 in December; P2: $600 \mathrm{~kg} \mathrm{ha}^{-1} \mathrm{P}_{2} \mathrm{O}_{5}$ applied at planting and every two years, and P3: $1800 \mathrm{~kg} \mathrm{ha}^{-1}$ of $\mathrm{P}_{2} \mathrm{O}_{5}$ applied only at planting, corresponding to a 6-year requirement), two water regimes (with and without irrigation) and three replications. Soil from the $0-5$ and 5-10 cm layers was sampled. The total organic carbon (TOC), labile carbon (LC), microbial carbon (Cmic), and carbon fractions of fulvic acid (FA), humic acid (HA) and humin (HU) were determined. The irrigation regime of coffee increased the TOC, LC and Cmic levels and the humified fractions of soil organic matter. In general, the form of P splitting had little influence on the fractions of soil organic matter.
\end{abstract}

Palavras-chave:

carbono lábil

fertilizante fosfatado

substâncias húmicas

\section{Frações da matéria orgânica em Latossolo com cafeeiro sob parcelamentos de fósforo e regimes hídricos}

\begin{abstract}
R E S U M O
A adubação fosfatada e o manejo da irrigação são essenciais para aumentar a produtividade do café; no entanto, há poucas informações sobre o efeito dessas práticas nas frações da matéria orgânica de solos de Cerrado. O objetivo deste trabalho foi avaliar frações da matéria orgânica de um Latossolo cultivado com cafeeiro sob parcelamentos de fósforo $(\mathrm{P})$ e regimes hídricos. $\mathrm{O}$ delineamento experimental foi em blocos ao acaso em arranjo fatorial $3 \times 2$, com três parcelamentos de $\mathrm{P}\left(\mathrm{P} 1: 300 \mathrm{~kg} \mathrm{ha}^{-1}\right.$ de $_{2} \mathrm{O}_{5}$ por ano, sendo 2/3 aplicados em setembro e 1/3 em dezembro; $\mathrm{P} 2$ : $600 \mathrm{~kg} \mathrm{ha}^{-1}$ de $\mathrm{P}_{2} \mathrm{O}_{5}$, aplicada no plantio e a cada dois anos e P3: $1.800 \mathrm{~kg} \mathrm{ha}^{-1} \mathrm{de}_{2} \mathrm{O}_{5}$ aplicada somente no plantio, necessária para seis anos); dois regimes hídricos (com e sem irrigação) e três repetições. A amostragem de solo foi feita nas camadas de 0-5 e 5-10 cm. Foram determinados o carbono orgânico total (COT) carbono lábil (CL), carbono microbiano (Cmic) e o carbono das frações ácido fúlvico (AF), ácido húmico (AH) e humina (HU). O regime hídrico irrigado do cafeeiro aumentou os teores do COT, CL, Cmic e das frações humificadas da matéria orgânica do solo. De maneira geral, a forma de parcelamento do P exerceu pouca influência sobre as frações da matéria orgânica do solo.
\end{abstract}

\section{INTRODUCTION}

Coffee production in Brazil in 2013 was approximately 49.15 million bags of processed coffee (CONAB, 2014) of which 38.29 million bags were of Arabica coffee and 10.86 million bags of coffee conilon, both grown in an area of approximately 2.01 million hectares. For coffee, water management is essential to obtain high yields (Pedroso et al., 2009), besides the synchronization of the development of the flower buds by a controlled water stress, especially for the conditions of the
'Cerrado' biome (Guerra et al., 2007). Moreover, the influence of irrigation is strongly dependent on climate and initial soil organic carbon content (Trost et al., 2013).

The predominant soils in the 'Cerrado' are Oxisols. Due to their high degree of weathering, these soils may have low nutrient availability, mainly due to the adsorption and precipitation of elements essential for plants. Thus, under natural conditions, these soils are extremely poor in plant-available $\mathrm{P}$, making P fertilization indispensable (Valladares et al., 2003). 
The irrigated coffee responded to phosphate fertilization in the production phase with gains of up to $138 \%$ in coffee yield by the application of $400 \mathrm{~kg} \mathrm{ha}^{-1} \mathrm{P}_{2} \mathrm{O}_{5}$ (Reis et al., 2011). In addition, the organic matter, responsible for most of the cation exchange capacity of these soils, is a key component to improve several properties of weathered soils.

The fertilizer and irrigation management influences the accumulation of soil organic matter in the more labile as well as the more stable fractions, e.g., the humic substances (Carmo et al., 2012). In the cultivation of perennial crops such as coffee, soil management, water and mineral fertilizers are essential factors for the input of organic waste and its humification (Partelli et al., 2009; Costa et al., 2013).

The recalcitrant organic matter fraction is formed by a set of products of plant and microbial residue decomposition that can be associated in supramolecular micelles (Dick et al., 2009). The solubility of the humic substances in aqueous medium, according to the $\mathrm{pH}$, permits the separation into three fractions: humin (HU), humic acid (HA) and fulvic acids (FA). In agricultural soils under coffee, the $\mathrm{HU}$ fraction was found to be predominant over the HA and FA fractions, due to its high stability and resistance to microbial degradation (Partelli et al., 2009; Rossi et al., 2011).

The labile soil fraction is represented by organic compounds readily available for mineralization by soil microbes. The labile carbon changes more than the total organic carbon content in a shorter time interval and is a fraction sensitive to changes in cropping systems (Rangel et al., 2008; Müller et al., 2012). The levels of labile $\mathrm{C}$ in coffee plantations represent on average $44 \%$ of the organic C content in the soil (Rangel et al., 2008).

The microbial biomass is defined as the living part of the soil organic matter, containing on average $2-5 \%$ of the organic $\mathrm{C}$ of the soil and in agricultural systems, microbial biomass plays a key role in nutrient cycling and can be changed by the input of organic residues (Diogenes et al., 2013) and soil management (Souza et al., 2010). The microbial biomass was high in coffee production systems with high nutrient concentrations and soil water availability (Costa et al., 2013).

There are only few studies on coffee that address the influence of water and P management on the fractions of soil organic matter. In this context, the purpose of this study was to evaluate the influence of water and $\mathrm{P}$ management on the organic matter fractions of soil under coffee in the 'Cerrado'.

\section{Material AND Methods}

The study was carried out in an experimental field of Embrapa Cerrados, in Planaltina, Distrito Federal (latitude $15^{\circ} 35^{\prime} 30^{\prime \prime} \mathrm{S}$, longitude $47^{\circ} 42^{\prime} 30^{\prime \prime} \mathrm{W} ; 1007 \mathrm{~m}$ asl). According to the Köppen classification, the climate is CWh1, with an annual precipitation of $1,460 \mathrm{~mm}$ and an average annual temperature of $21.3^{\circ} \mathrm{C}$. The soil is classified as a clayey Oxisol horizon with a moderate A horizon and $0.20 \mathrm{~m}$ thick.

Prior to the experiment, the chemical analysis of the soil in the $0-0.20 \mathrm{~m}$ layer showed the following results: $\mathrm{pH}$ in water 5.2; $\mathrm{Al}^{3+}\left(4.3 \mathrm{mmol}_{\mathrm{c}} \mathrm{dm}^{-3}\right) ; \mathrm{Ca}^{2+}\left(22.9 \mathrm{mmol}_{\mathrm{c}} \mathrm{dm}^{-3}\right) ; \mathrm{Mg}^{2+}(8.3$ $\left.\mathrm{mmol}_{\mathrm{c}} \mathrm{dm}^{-3}\right) ; \mathrm{H}+\mathrm{Al}\left(76.0 \mathrm{mmol}_{\mathrm{c}} \mathrm{dm}^{-3}\right) ; \mathrm{P}\left(1.4 \mathrm{mg} \mathrm{dm}^{-3}\right) ; \mathrm{K}$ $\left(61.2 \mathrm{mg} \mathrm{dm}^{-3}\right)$; aluminum saturation (12\%). The average clay, silt, coarse sand, and fine sand contents are 601, 116, 47, and $236 \mathrm{~g} \mathrm{~kg}^{-1}$, respectively.

Before the installation of the experiment, the area was covered by ungrazed brachiaria (Brachiaria decumbens). In December 2007, the experiment was initiated by planting coffee (Coffea arabica L. cultivar IAC144), with a spacing of $3.50 \mathrm{~m}$ between rows and $0.70 \mathrm{~m}$ between plants. At planting, fertilization consisted of $120 \mathrm{~g}$ triple superphosphate (TSP), 50 $\mathrm{g}$ termalphosphate (Yoorin ${ }^{\circ}$ ) and $24.5 \mathrm{~g}$ fritted trace elements (FTE) per planting hole. Liming was $2 \mathrm{Mg} \mathrm{ha}^{-1}$ of lime to raise base saturation to $50 \%$, half applied before plowing and the rest before harrowing.

In the year after planting, the crop was fertilized with $61.25 \mathrm{~g} \mathrm{~N}$ per hill, in the form of urea, corresponding to 136 $\mathrm{g}$ fertilizer. Similarly, $61.25 \mathrm{~g} \mathrm{~K}_{2} \mathrm{O}$ was applied, in the form of potassium chloride $(\mathrm{KCl})$, corresponding to $102 \mathrm{~g}$ fertilizer per plant. In both cases, the doses were split into four applications in the period from September to February. In the other years, following the same form of splitting, annual doses of $272 \mathrm{~g}$ urea and a maximum of $204 \mathrm{~g} \mathrm{KCl}$ were applied per hole, and $\mathrm{KCl}$ varied according to the soil $\mathrm{K}$ reserve, determined by the chemical analysis. A micronutrient fertilizer was applied, when necessary, with the FTE fertilizer. All fertilizer doses were applied manually, under the coffee canopy.

The experimental design was a randomized block with three replications in a $3 \times 2$ factorial arrangement, with three $P$ rates (P1, P2 and P3) and two water regimes (R: rainfed and I: year-round irrigation).

The assay was designed for an experimental monitoring period of six years, after which all treatments had received the same amount of P. The fertilization was applied as defined for each treatment, beginning in the second year after planting. Treatments were defined based on a basic annual module of 300 $\mathrm{kg} \mathrm{ha}^{-1}$ of $\mathrm{P}_{2} \mathrm{O}_{5}$, corresponding to treatment $\mathrm{P} 1$, in which annually $117 \mathrm{~g}$ TSP was applied per plant, $78 \mathrm{~g}(2 / 3)$, in September, and $39 \mathrm{~g}(1 / 3)$ in December. In treatment $\mathrm{P} 2,600 \mathrm{~kg} \mathrm{ha}^{-1} \mathrm{P}_{2} \mathrm{O}_{5}$, two fertilization modules were applied at once, equivalent to 233 g TSP per plant in September, repeated every two years. In treatment $\mathrm{P} 3,1800 \mathrm{~kg} \mathrm{ha}^{-1} \mathrm{P}_{2} \mathrm{O}_{5}$, the complete fertilization for six years was applied at once, corresponding to $700 \mathrm{~g}$ TSP per plant. Thus, at the time of soil sampling, treatments $\mathrm{P} 1$ and $\mathrm{P} 2 \mathrm{had}$ received $66.6 \%$ of the $\mathrm{P}$ scheduled for six years and treatment P3 100\% of the requirement.

In the irrigated management, water was applied by a center pivot, according to the level of the monitored soil water content (Theta probe soil moisture sensor, type ML1, Delta-T Devices). Irrigation was applied when the soil moisture at $0.10 \mathrm{~m}$ depth corresponded to the consumption of $50 \%$ of available soil water.

Soil samples were collected in April 2013 in the fruiting period, below the coffee canopy, in the layers $0-5$ and $5-10 \mathrm{~cm}$, resulting in a sample of five subsamples per plot in each soil layer, water regime and for each $\mathrm{P}$ rate. Then, the samples were homogenized, packed in plastic bags and stored in a refrigerator for about 10 days at $4{ }^{\circ} \mathrm{C}$, until microbiological analysis. For 
chemical analysis, the soil was air-dried and sieved $(2 \mathrm{~mm}$ mesh).

In soil total organic carbon (TOC) was determined by wet oxidation with potassium dichromate in the presence of sulfuric acid with no external heat source (Nelson \& Sommers, 1982). The microbial biomass carbon (MBC) was determined by extraction irradiation, according to Islam \& Weil (1998), at a $\mathrm{K}_{\mathrm{EC}}$ factor of 0.33 .

The carbon of humic fractions of organic matter (fulvic acid, humic acid and humin) was determined according to the methodology described by Mendonça \& Matos (2005). $1 \mathrm{~g}$ of air-dried fine soil sample was placed in $50 \mathrm{~mL}$ centrifuge tubes with a lid and $20 \mathrm{~mL}$ of $0.1 \mathrm{~mol} \mathrm{~L}^{-1} \mathrm{NaOH}$ (ratio 1:20) was added as extractant. The fulvic acid fraction was obtained from the soluble portion of the alkaline extract, humic acid fraction of the precipitate in acid and humin fraction in the precipitate after centrifugation in alkaline extractor. After extraction, the carbon of the humic fractions was quantified by oxidation with potassium dichromate C (Nelson \& Sommers, 1982).

The content of labile $\mathrm{C}$ in the samples was determined by sample oxidation with $0.033 \mathrm{~mol} \mathrm{~L}^{-1}$ potassium permanganate and the reading of the extracts in a spectrophotometer at 565 $\mathrm{nm}$ (Mendonça \& Matos, 2005).

The data were subjected to analysis of variance (ANOVA) and the means compared by Tukey's test $(\mathrm{p}<0.05)$, using the statistical program Assistat (Silva \& Azevedo, 2002). Pearson's linear correlation analysis was also used to group the data of $\mathrm{P}$ rates, layers and water regimes.

The data for all variables together were subjected to principal component analysis (PCA), based on linear combinations of the original variables on independent orthogonal axes. This analysis was performed to identify which factors (water regime and $\mathrm{P}$ rate) most affected the clustering of the variables (CBM, TOC, labile $\mathrm{C}$ and humic fractions of organic matter), using software XLSTAT 2013.

\section{RESULTS AND Discussion}

Analysis of variance showed significant effects of the factors split applications of $\mathrm{P}$ and water regime, and of their interactions on total organic carbon (TOC), microbial carbon (Cmic), labile carbon (LC) and humified organic matter fractions, fulvic acid (FA), humic acid (HA) and humin (HU) in both soil layers
(Table 1). All properties evaluated were affected by the factor water regime.

The effect of water regime on all fractions of soil organic matter (SOM) was strong, regardless of the form of splitting $\mathrm{P}$ fertilization. The levels of labile and humified organic matter were highest in the irrigated system in both soil layers (Table 2). Coffee biomass increased by irrigation (Perdoná et al., 2012; Evangelista et al., 2013), with a consequent increase in SOM, leading to the accumulation in its different fractions (Loss et al., 2013).

In the 0-5 cm layer effect of irrigation was observed on both Cmic and humified fractions of SOM (FA, HA and HU). The increase in microbial biomass is determined by the water and nutrient availability in the soil, mainly by the presence of the organic substrate (Diógenes et al., 2013) and plays an important role in mineralization and humification of organic matter (Figueiredo et al., 2012). Matei et al. (2012) found that water availability in the soil favors growth and diversity of the microbial population and also the quantity and quality of fulvic acids (FA) in the soil surface horizons.

For rainfed systems and irrigation regimes, the HA fraction accounted for 16.53 and $20.92 \%$, the HU fraction for 23.81 and $23.37 \%$ and LC for 8.37 and $7.91 \%$ of TOC, respectively, in the 5-10 cm layer. Irrigation increased the percentage of the $\mathrm{HA}$ fraction and decreased the percentage of $\mathrm{HU}$ in relation

Table 2. Total organic carbon (TOC), microbial carbon (Cmic), labile carbon (LC) and carbon in fulvic acid (FA), humic acid (HA) and humin (HU) fractions in two soil layers under coffee crop with split phosphorus fertilization rates and water regimes

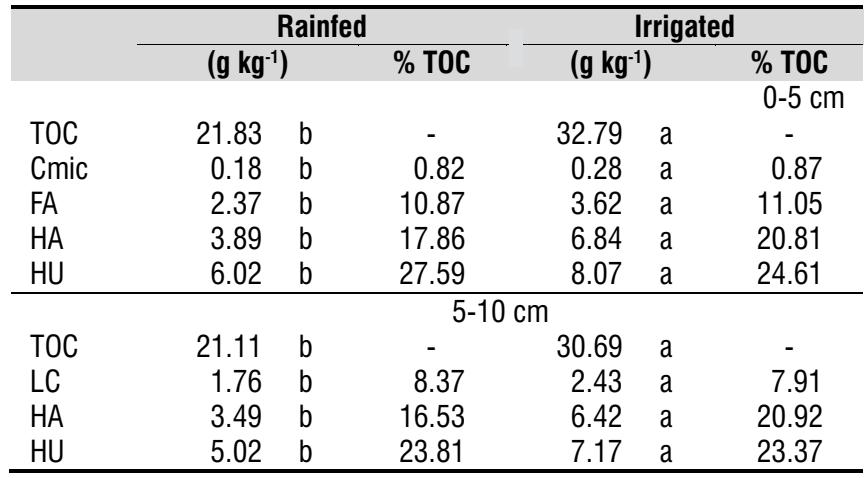

Means followed by the same letter in the row do not differ by Tukey's test $(p<0.05)$

Table 1. Summary of the analysis of variance of the effects of water regimes, phosphate fertilization of soil under coffee on total organic carbon (TOC), microbial carbon (Cmic), labile carbon (LC), and carbon in the fractions fulvic acid $(\mathrm{FA})$, humic acid $(\mathrm{HA})$ and humin $(\mathrm{HU})$ in the 0-5 and 5-10 cm layers

\begin{tabular}{|c|c|c|c|c|c|c|c|}
\hline FV & DF & TOC & Cmic & LC & FA & HA & HU \\
\hline WR & 1 & $450.8229^{* *}$ & $65.873^{\star \star}$ & $59.240^{\star \star}$ & $33.277^{\star \star}$ & $86.2135^{\star \star}$ & $12.989^{\star \star}$ \\
\hline PS & 2 & $0.4250^{\text {ns }}$ & $3.2339^{\text {ns }}$ & $2.8472^{\text {ns }}$ & $0.5197^{\text {ns }}$ & $0.0664^{\text {ns }}$ & $0.5119^{\text {ns }}$ \\
\hline WR $\times$ PS & 2 & $3.3735^{\text {ns }}$ & $0.2805^{\text {ns }}$ & $5.5144^{*}$ & $0.4737^{\text {ns }}$ & $0.2360^{\text {ns }}$ & $0.3753^{\text {ns }}$ \\
\hline \multicolumn{8}{|c|}{$5-10 \mathrm{~cm}$} \\
\hline WR & 1 & $245.6118^{* *}$ & $118.759^{* *}$ & $65.101^{\star *}$ & $95.172^{* *}$ & $132.759^{* *}$ & $28.294^{* *}$ \\
\hline PS & 2 & $4.1575^{\star}$ & $2.0491^{\mathrm{ns}}$ & $1.433^{\text {ns }}$ & $0.9677^{\text {ns }}$ & $0.0953^{\text {ns }}$ & $3.0097^{\text {ns }}$ \\
\hline WR $\times P S$ & 2 & $3.7880^{\text {ns }}$ & $7.2204^{*}$ & $1.286^{\text {ns }}$ & $6.7019^{\star}$ & $1.7073^{\mathrm{ns}}$ & $0.4896^{\text {ns }}$ \\
\hline
\end{tabular}

SV - Source of variation; DF - Degrees of freedom; WR - Water regime; PS - Phosphorus splitting; ${ }^{*}$, ${ }^{* *}$ Significant at 0.05 and 0.01 , respectively, by the F test; nsNon significant 
to TOC. Campos et al. (2013) reported higher humification rates of organic matter added to the soil in the conventional tillage system in the dry than in the rainy season, however in the no-tillage system, the humification rates were lowest in the dry period. The results obtained showed that the soil and water regime management are important factors in the humification of soil organic matter.

In the $0-5 \mathrm{~cm}$ layer, irrigation induced higher labile carbon (LC) contents under P3 (Table 3 ) than P rates. In this layer, irrigation promoted increases of 1.69, 1.32 and 1.2 times the LC contents under P3, P2 and P1 rates, respectively. The increasing levels of $\mathrm{P}$ in the soil stimulated coffee root growth (Matsumoto et al., 2008; Martins et al., 2013). Thus, the increase of the root system favors an increased aggregation rate of the soil and consequently, improves the protection of organic matter and contributes to an increase in soil LC (Müller et al., 2012).

Compared to the rainfed system, irrigation promoted higher levels of LC at all split applications of P, as similarly observed for the FA fraction in the $5-10 \mathrm{~cm}$ layer. Irrigated agricultural systems with frequent additions of organic material to the soil tend to build up higher proportions of carbon in the labile fraction, at the expense of the recalcitrant fractions (Rangel et al., 2008). In irrigated coffee, soil $P$ application caused, in general, an increase in bioavailable $P$ fractions (Reis et al., 2011).

The contents of Cmic in the $5-10 \mathrm{~cm}$ layer were higher under irrigation than in the rainfed system, regardless of the split application of $\mathrm{P}$. In this layer, there was no difference in Cmic between $\mathrm{P}$ rates under irrigation, while in the rainfed system Cmic was higher at the annually applied rate of $300 \mathrm{~kg}$ ha $^{-1} \mathrm{P}_{2} \mathrm{O}_{5}(\mathrm{P} 1)$.

The adsorbability of phosphate ions to the colloids of electropositive soils process is high (Valladares et al., 2003), making the nutrient unavailable for crops and soil microorganisms (Gatiboni et al., 2008). Thus the supply of a high amount of $\mathrm{P}$ to coffee in a single application can affect the Cmic levels, due to the unavailability of this nutrient to the soil microorganisms in the years after fertilization.

Two principal components (CP1 and CP2) were generated, which were used as tools to distinguish the effects of irrigated

Table 3. Interaction between water regime and phosphorus on labile carbon (LC), microbial carbon (Cmic) and carbon in fulvic acid fraction (FA) in two layers of soil under coffee

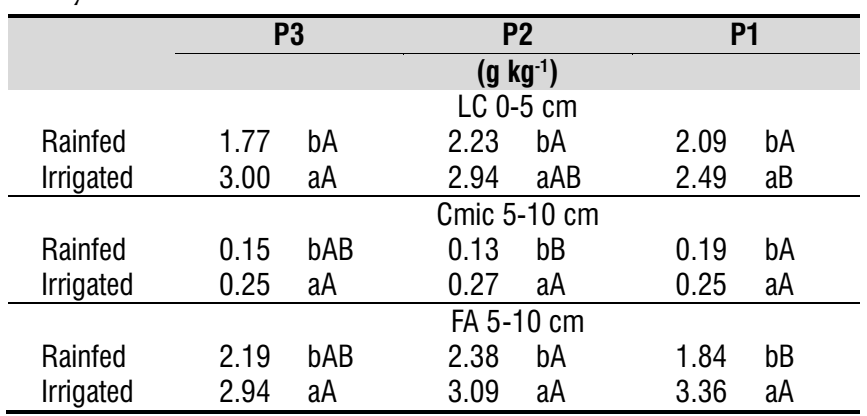

$\mathrm{P} 1=300 \mathrm{P}_{2} \mathrm{O}_{5} \mathrm{~kg} \mathrm{ha}^{-1}$, applied annually $-2 / 3$ of the dose in September and $1 / 3$ in December; $\mathrm{P} 2=600 \mathrm{~kg} \mathrm{P}_{2} \mathrm{O}_{5}$ ha $^{-1}$, reapplied every two years; P3 $=1800 \mathrm{~kg} \mathrm{P}_{2} \mathrm{O}_{5}$ ha $^{-1}$, applied only at planting; Means followed by lowercase letters in the column and uppercase letters in the row, do not differ by Tukey's test $(p<0.05)$ and rainfed water regimes, considering the TOC, LC, Cmic and humified fractions of soil organic matter (FA, HA and $\mathrm{HU}$ ) together, for the layers $0-5 \mathrm{~cm}$ (Figure $1 \mathrm{~A}$ ) and $5-10 \mathrm{~cm}$ (Figure 1B).

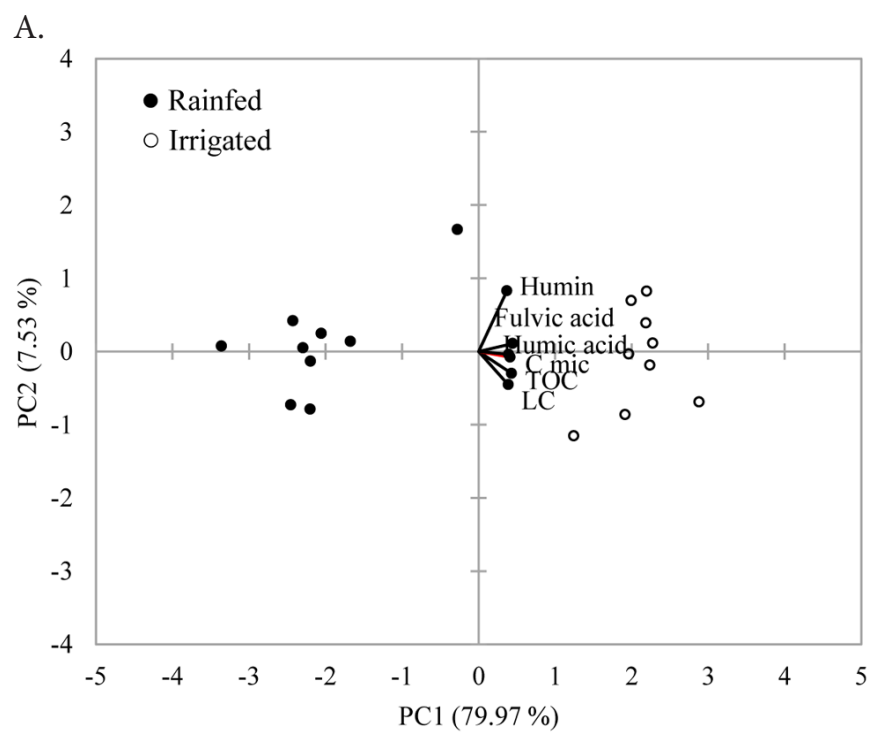

B.

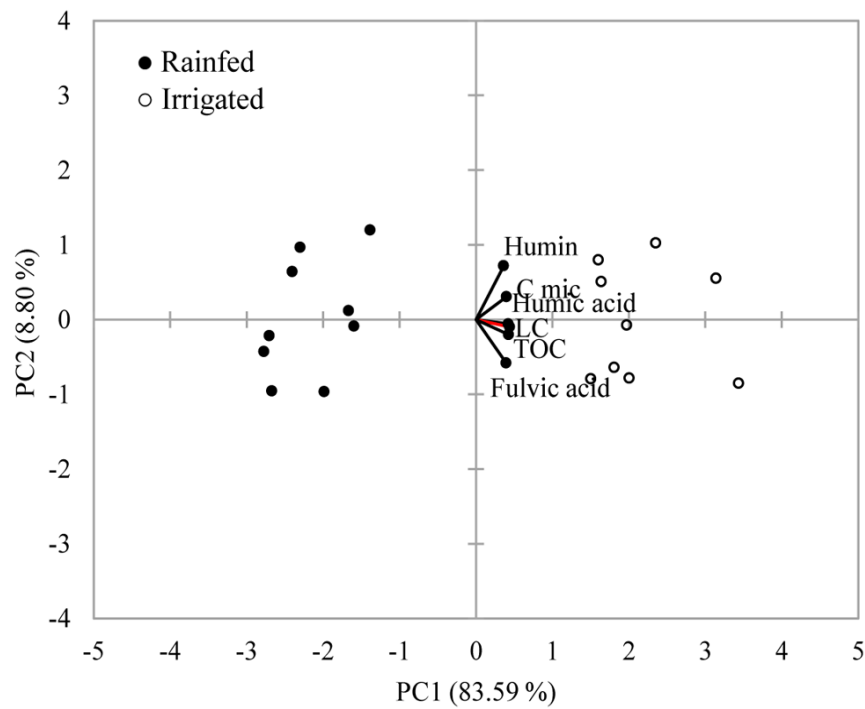

Figure 1. Ordination diagram based on principal component analysis of scores of $P$ rate and water regime treatments. $0-5 \mathrm{~cm} \mathrm{(A);} \mathrm{5-10} \mathrm{cm} \mathrm{(B)}$

Similar patterns were observed in both soil layers. The distribution of selected variables showed cumulative variance of 87.49 and $92.40 \%$ for the sum of the principal components PC1 and PC2 in the 0-5 and 5-10 cm layers, respectively. In both layers, the CP1 axis separated two groups: irrigated and rainfed. This means that, considering all properties together, irrigation had a prevailing effect, forming distinct environments for the soil microbiota and for the accumulation of TOC, LC and humified SOM fractions. Similar results were obtained by Costa et al. (2013), who described the water regime as determinant for the distribution of the variables $\mathrm{Cmic}$, TOC and oxidizable SOM fractions. An improved water supply leads to an increased biomass generation and therefore to a higher input of carbon 
into the soil in the form of roots and dead plant material (Trost et al., 2013).

The correlation of the LC and FA and HA fractions with Cmic and TOC was positive and highly significant (Table 4), indicating a close relationship between the more labile SOM fractions and the activity of soil microorganisms. These results corroborate those of Cunha et al. (2011), who observed a positive correlation between TOC and Cmic. High levels of Cmic reflect the presence of a high amount of active organic matter in the soil, which can maintain a high mineralization rate of plant residues (Stone et al., 2013).

Table 4. Pearson correlation between properties of organic matter in an Red Latosol with coffee under three phosphorus rates and two water regimes, in two layers

\begin{tabular}{ccccccc}
\hline Variables & HU & Cmic & LC & FA & HA & TOC \\
HU & 1 & $0.708^{\star *}$ & $0.684^{\star *}$ & $0.637^{\star *}$ & $0.767^{\star *}$ & $0.705^{\star *}$ \\
Cmic & & 1 & $0.722^{\star *}$ & $0.720^{\star *}$ & $0.801^{\star \star}$ & $0.839^{\star *}$ \\
LC & & & 1 & $0.770^{\star \star}$ & $0.808^{\star \star}$ & $0.861^{\star *}$ \\
FA & & & & 1 & $0.883^{\star \star}$ & $0.857^{\star *}$ \\
HA & & & & & 1 & $0.927^{\star *}$ \\
TOC & & & & & & 1 \\
\hline
\end{tabular}

HU - Humin; Cmic - Microbial carbon; LC - Labile carbon; FA - Fulvic acid; HA - Humic acid; $\mathrm{HU}$ - Humin; TOC - Total organic carbon; ${ }^{\star}$ Significant at 0.05 by the $\mathrm{F}$ test

The TOC was also positively correlated with the fractions FA (0.85), HA (0.92) and HU (0.70), demonstrating the high participation of humified fractions in SOM, especially of the less humified fractions (FA and HA). Higher proportions of these fractions improve the chemical quality of soils. Partelli et al. (2009) found a positive correlation between the humified SOM fractions and cation exchange capacity in soils of various organic management systems.

\section{Conchusions}

1. Irrigation of coffee grown in the 'Cerrado' promoted increase in levels of total organic carbon, microbial carbon, and of the labile and humified fractions of soil organic matter.

2. In general, the form of $\mathrm{P}$ splitting had little influence on the fractions of soil organic matter. Only the rate of $1800 \mathrm{~kg} \mathrm{ha}^{-1}$ of $\mathrm{P}_{2} \mathrm{O}_{5}$ under irrigation increased the levels of labile carbon.

3. Regardless of the soil layer, the water regime and split applications of $\mathrm{P}$, microbial carbon showed strong interactions with the content of total organic carbon and labile carbon and with the humic acid and fulvic acid fractions of soil organic matter.

\section{Literature Cited}

Campos, L. P.; Leite, L. F. C.; Maciel, G. A.; Brasil, E. L.; Iwata, B. F. Estoques e frações de carbono orgânico em Latossolo Amarelo submetido a diferentes sistemas de manejo. Pesquisa Agropecuária Brasileira, v.48, p.304-312, 2013.

Carmo, F. F.; Figueiredo, C. C.; Ramos, M. L. G.; Vivaldi, L. J.; Araújo, L. G. Frações granulométricas da matéria orgânica em Latossolo sob plantio direto com gramíneas. Bioscience Journal, v.28, p.420-431, 2012.
CONAB - Companhia Nacional de Abastecimento. Acompanhamento da safra brasileira de café: Safra 2013. Brasília: CONAB, 2014. 61p.

Costa, A. R.; Sato, J. H.; Ramos, M. L. G.; Figueiredo, C. C. Souza, J. P. Rocha, O. C.; Guerra, A. F. Microbiological properties and oxidizable organic carbon fractions of an Oxisol under coffee with split phosphorus applications and irrigation regimes. Revista Brasileira de Ciência do Solo, v.37, p.55-65, 2013.

Cunha, E. Q.; Stone, L. F.; Moreira, J. A. A.; Ferreira, E. P. B.; Didonet, A. D.; Leandro, W. M. Sistemas de preparo do solo e culturas de cobertura na produção orgânica de feijão e milho. I - Atributos físicos do solo. Revista Brasileira de Ciência do Solo, v.35, p.589-602, 2011.

Dick, D. P.; Novotny, E. H.; Dieckow, J.; Bayer, C. Química da matéria orgânica do solo. In: Melo, V. F.; Alleoni, L. R. F. Química e mineralogia do solo. Viçosa: SBCS, 2009. Cap.1, p.1-67.

Diógenes, L. C.; Nóbrega, J. C. A.; Nóbrega, R. S. A.; Andrade Júnior, A. S.; Pragana, R. B.; Matias, S. S. R. Microbial attributes and carbon and nitrogen stocks in Latosol under irrigated monocropping and intercropping. Revista de Ciências Agrárias, v.56, p.106-111, 2013.

Evangelista, A. W. P.; Alves Júnior, J.; Melo, P. C. Resposta do cafeeiro à aplicação de níveis de irrigação e adubação com Alfertil. Revista Brasileira de Engenharia Agrícola e Ambiental, v.17, p.392-396, 2013.

Figueiredo, C. C.; Ramos M. L. G.; McManus, C. M.; Menezes, A. M. Mineralização de esterco de ovinos e sua influência na produção de alface. Horticultura Brasileira, v.30, p.175179, 2012.

Gatiboni, L. C.; Kaminski, J.; Rheinheimer, D. S.; Brunetto, G. Fósforo da biomassa microbiana e atividade de fosfatases ácidas durante a diminuição do fósforo disponível no solo. Pesquisa Agropecuária Brasileira, v.43, p.1085-1091, 2008.

Guerra, A. F.; Rocha, O. C.; Rodrigues, G. C.; Sanzonowics, C.; Ribeiro Filho, G. C.; Toledo, P. M. R.; Ribeiro, L. F. Sistema de produção de café irrigado: Um novo enfoque. Irrigação \& Tecnologia Moderna, v.73, p.52-61, 2007.

Islam, K. R.; Weil, R. R. Microwave irradiation of soil for routine measurement of microbial biomass carbon. Biology and Fertility of Soils, v.27, p.408-416, 1998.

Loss, A.; Coutinho, F. S.; Pereira, M. G.; Silva, R. A. C.; Torres, J. L. R.; Ravelli Neto, A. Fertilidade e carbono total e oxidável de Latossolo de Cerrado sob pastagem irrigada e de sequeiro. Ciência Rural, v.43, p.426-432, 2013.

Martins, L. D.; Tomaz, M. A.; Amaral J. F. T.; Christo L. F.; Rodrigues W. N.; Colodetti T. V.; Brinati S. V. B. Alterações morfológicas em clones de cafeeiro conilon submetidos a níveis de fósforo. Scientia Plena, v.9, p.1-11, 2013.

Matei, G.; Matei, S.; Mocanu, V.; Seceleanu, I.; Coteţ, V.; Dumitru, S. Study on microbial communities and soil organic matter in irrigated and non-irrigated vertisol from Boianu. Soil Forming Factors and Processes from the Temperate Zone, v.11, p.1-8, 2012. 
Matsumoto, S. N.; Carvalho, F. M.; Viana, E. S. V.; Malta, M. R.; Castro, L. G. Initial growth of coffee plants (Coffea arabica L.) submitted to different phosphate doses in nutritive solution. Coffee Science, v.3, p.58-67, 2008.

Mendonça, E. S.; Matos, E. S. Matéria orgânica do solo: Métodos de análises. Viçosa: UFV, 2005. 107p.

Müller, C. B.; Weber, O. L. S.; Scaramuzza, J. F. Oxidizable fraction of organic carbon in an Argisol under different land use systems. Cerne, v.18, p.215-222, 2012.

Nelson, D. W.; Sommers, L. E. Total carbon, organic carbon, and organic matter. In: Page, A. L.; Miller, R. H.; Keeney, D. R. (ed.). Methods of soil analysis chemical and microbiological properties. Part 2. 2.ed. Madison: American Society of Agronomy and Soil Science Society of America, 1982. p.539-577.

Partelli, F. L.; Busato, J. G Vieira, H. D.; Viana, A. P.; Canellas, L. P. Qualidade da matéria orgânica e distribuição do fósforo no solo de lavouras orgânicas de café Conilon. Ciência Rural, v.39, p.2065-2072, 2009.

Pedroso, T. Q.; Scalco, M. S.; Carvalho, M. L. M.; Resende, C. A.; Otoni, R. R. Qualidade de sementes de cafeeiro produzidas em diferentes densidades de plantio e regimes hídricos. Coffee Science, v.4, p.155-164, 2009.

Perdoná, M. J.; Soratto, R. P.; Martins, A. N.; Suguino, E.; Mancuso, M. A. C. Irrigação e certificação da cafeicultura na Região Centro-Oeste de São Paulo. Bragantia, v.71, p.377-384, 2012.

Rangel, O. J. P; Silva, C. B; Guimarães, P. T.; Guilherme, L. R. G. Frações oxidáveis do carbono orgânico de Latossolo cultivado com cafeeiro em diferentes espaçamentos de plantio. Ciência e Agrotecnologia, v.32, p.429-437, 2008.
Reis, T. H. P.; Guimarães, P. T. G.; Furtini Neto, A. E.; Guerra, A. F.; Curi, N. Soil phosphorus dynamics and availability and irrigated coffee yield. Revista Brasileira de Ciência do Solo, v. 35, p.503-512, 2011.

Rossi, C. L.; Pereira, M. G.; Giacomo, S. G.; Betta, M.; Polidoro, J. C. Frações húmicas da matéria orgânica do solo cultivado com soja sobre palhada de braquiária e sorgo. Bragantia, v.70, p.622-630, 2011.

Silva, F. de A. S. e; Azevedo, C. A. V. de. Versão do programa computacional Assistat para o sistema operacional Windows. Revista Brasileira de Produtos Agroindustriais, v.4, p.71-78, 2002.

Souza, E. D.; Costa, S. E. V. G. A.; Anghinoni, I.; Lima, C. V. S.; Carvalho, P. C. F.; Martins, A. P. Biomassa microbiana do solo em sistema de integração lavourapecuária em plantio direto, submetido a intensidades de pastejo. Revista Brasileira de Ciência do Solo, v.34, p.79-88, 2010.

Stone, L. F.; Ferreira, E. P.; Didonet, A. D.; Heinemann, A. B. Oliveira, J. P. Correlação entre a produtividade do feijoeiro no sistema de produção orgânica e atributos do solo. Revista Brasileira de Engenharia Agrícola e Ambiental, v.17, p.19$25,2013$.

Trost, B.; Prochnow, A.; Drastig, K.; Meyer-Aurich. A.; Ellmer, F.; Baumecker, M. Irrigation, soil organic carbono and $\mathrm{N}_{2} \mathrm{O}$ emissions. A review. Agronomy for Sustainable Development, v.33, p.733-749, 2013.

Valladares, G. S.; Pereira, M. G.; Anjos, L. H. C. Adsorção de fósforo em solos de argila de atividade baixa, Bragantia, v.62, p.111-118, 2003. 